friends has assured me that I was perfectly justified in my statement on this point ; and it was by one of these, who was present at the lecture in question, that I was informed of the very.explicit statement made on that occasion by $\mathrm{Mr}$. Crookes of the views he then held, which were universally understood in their plain common-sense meaning.

November 20

William B. Carpenter

\section{Fluid Films}

WrTH reference to $\mathrm{Mr}$, Sedley Taylor's interesting note on Fluid Films, allow me to say that if a drop of water, clinging to the outside of a glass goblet, be lightly dusted with lycopodium powder, and a fiddle-bow be drawn across the edge of the glass, the drop will exhibit vortices, rotating in opposite directions.

Highgate, N., November 19

C. TOMLINSON \section{Tuckey and Stanley. - The Yallala Rapids on the
Congo}

CAPT. TUCKEY is dead and gone and cannot answer for him self; it may therefore, perhaps, serve to clear his memory in some measure of a doubt about the correctness of his description of the Yallala Rapids in 1816 , arising from the very different account of them given by Stanley sixty years afterwarủs, if I mention one of several facts in connection with American rivers.

The late Sir J. Franklin, in his first and disastrous overland journey to the Arctic Sea in I82I, describes the "Bloody Fall" on the Coppermine River as " a shelving cascade about three hundred yards in length, having a descent of ten or fifteen feet."

Betwe $\in$ in i 848 and I 85 I this "fall" was visited five times; on one or other of such occasions the water was either at high spring flood, at low summer level, or at an intermediate elevation, yet under none of these conditions was the "fall" found to be more than thirty yards long, if so much, the height being about fifteen feet.

Franklin and the officers with him were most careful and correct observers, so that $\bar{I}$ can only attribute this wonderful change (from three hundred yards long to thirty) in the form of the cascade to the wearing away of the material forming the bed of the river, by the action of the water, assisted in a great measure by the large masses of ice and the stones carried down with it during the breaking up of the navigation in the course of thirty seasons, only half the interval of time between Tuckey's and Stanley's visits to the Congo.

Supposing a somewhat similar attrition, but in a less rapid manner, to have been going on at the Yallala Rapid, the description given by the former as he saw it may be equally correct as that of the latter when he visited it in its altered shape in $187 \%$.

May I add that a cataract may become a fall or a series of falls, and vice verstis according as the water in a river is in flood or at low level.

Scientific Club, November 16

\section{The Future of our British. Flora}

IT may interest Mr. Shaw to know that the stations given by Lightfoot in his "Flora Scotica, 1777," still exist (as far as I am aware, and $I$ have visited by far the greater number of them) at the present day. Experience has led me to the conclusion that a plant however maltreated, does not become extinct unless the natural conditions are changed, as by the draining of a marsh, \&c. I have over and over again found plants in stations where they were reported as "extinct years ago." Perhaps if Mr. Shaw visits his station for the "Lizard Orchis" (is this Orchis hircina, L.? if so it is, I fancy, new to Scotch botanists) in the course of a year or two he may find it in as large quantity as ever. As regards the maltreatment of plants, I agree with what Mr. Shaw says respecting professors of botany. Each teacher of the science ought to teach his students that it is a crime to exterminate a plant, and that they can best learn botany from the observation of the common plants of their district; there is great room for improvement in this respect.

While a student I was often disgusted by seeing rare plants torn up and then cast away as if they had been a handful of grass, or, worse still, put in the vasculum and forgotten till the next Saturday, when they were thrown away; and all this without a word of remonstrance from those who ought to have exercised authority, "that's villainous, and shows a most pitiful ambition in the man who uses it."

Provided we reform a little, I do not think that, judging of the future by the past we have any reason to expect a large decrease in the ranks of our native flora. I do not suppose any species given by Lightfoot 100 years ago has become extinct even in his stations, and on the other hand we have bad a considerable number added to it since his time.

Edinburgh

\section{A. Craig-Christie}

\section{Selective Discrimination of Insects}

IN continuation of the interesting observations of "S. B." on selective discrimination of insects in NATURE, vol. xvi. p. 522, permit me to send you? the following notes from my journal, made in August last :-

"Watched by the roadside near Kew Bridge Station, severa.l species of Hymenoptera, of the genus Bombus principally; one visited thirty flowers of Lamium purpureum in succession, passing over withoutinotice all the other plants in flower on the same bank-species of Convolvulus, Rubus, Solanum. Two other species of Bombus and a Pieris rapie also patronised the Lamizm, seeking it out deep in the thicket, thrusting their probosces even into withered cups, although the Rubus' flowers were far inore accessible and seemed much more attractive, being fresh and well-expanded.

"On the same bank severai species of Diptera-Syrphuschiefly -were visiting the Rubus, ignoring the Lamizus. On another bank, some distance removed from the first, I observed, how ever, that the diptera were visiting the Laminm (one species was very busy on the convolvulus, applying its proboscis to the external aspect of the anther) while the Hymenoptera, species of wasp, were giving their attention to the Rubus."

I am sorry not to be in a position to identify the species of Hymenoptera and Diptera, being unable to capture specimens of either.

Highgate, N.

HENRY O, FORBES

\section{The Earth-worm in Relation to the Fertility of the Soil}

In your number of the 8th instant there are some interesting remarks upon the habits, \&c., of the common earth-worm. From frequent observations I fully concur with the remark that the worm does not consume living vegetation but only vegetable matter undergoing decomposition.

I am also rather inclined to the opinion that there are (or may be) two reasons for the drawing in to their holes dead leaves, \&c., the one being, for use as food, and the other to protect the holes from a too plentiful supply of water.

In this same connection I may mention what I have not before seen mention of, namely, the little mounds of small gravel stones which the worms heap up around the entrance to their holes, These are very curious and may be partly to prevent the entrance of water; and also, as I think, partly for rubbing against the worm's slimy body, as fish do.

It is very remarkable the extent to which loose gravel-stones (some as large as a hazel-nut, and even larger) are removed from a gravel-walk from distances quite beyond a foot, leaving the walk pitted all over. I have never seen a worm in the act of moving these stones and it is difficult to imagine how it is done, but as it generally takes place in wet weather, it may probably be by an adhesion of the stone to the slimy body of the worm.

As regards fertilising effects, it would be interesting to know whether the earthy matter composing worm-casts had passed through the worm's body, as the writer supposes, for in that'case it would probably have more fertilising properties than if consisting merely of the natural soil thrown up as by moles.

The remark by one of your correspondents as to his observation of a line of darker soil thrown up by worms from a substratum of ashes deposited a considerable time before, would almost make it appear that the mole-like action above referred to took place. The writer, however, repeats his conviction that the matter composing worm-casts has passed through its (the worm's) body. 3I, Stockwell Park Road Geo. H. Phipps

\section{Smell and Hearing in Moths}

"J. C." seems to draw inferences that moths have not the power of smell but have that of hearing. I feel quite certain they possess the former, but am in doubt about the latter. For the purpose of catching moths I use a preparation of beer and 